PENGEMBANGAN MULTIMEDIA

PEMBELAJARAN INTERAKTIF KIMIA

BERBASIS ANDROID

Perkembangan teknologi yang semakin pesat, menuntut para pendidik untuk mampu mengembangkan media pembelajaran yang sesuai dengan tuntutan generasi milenial. Penggunaan smartphone oleh generasi milenial dapat dijadikan peluang yang ampuh dalam memberikan suplemen pembelajaran kepada peserta didik.

Buku pengembangan multimedia pembelajaran interkatif kimia berbasis android ini dapat dijadikan bahan referensi bagi tenaga pendidik dalam mengembangan media pembelajaran yang interaktif dan berbasis android. BERBASIS ANDROID
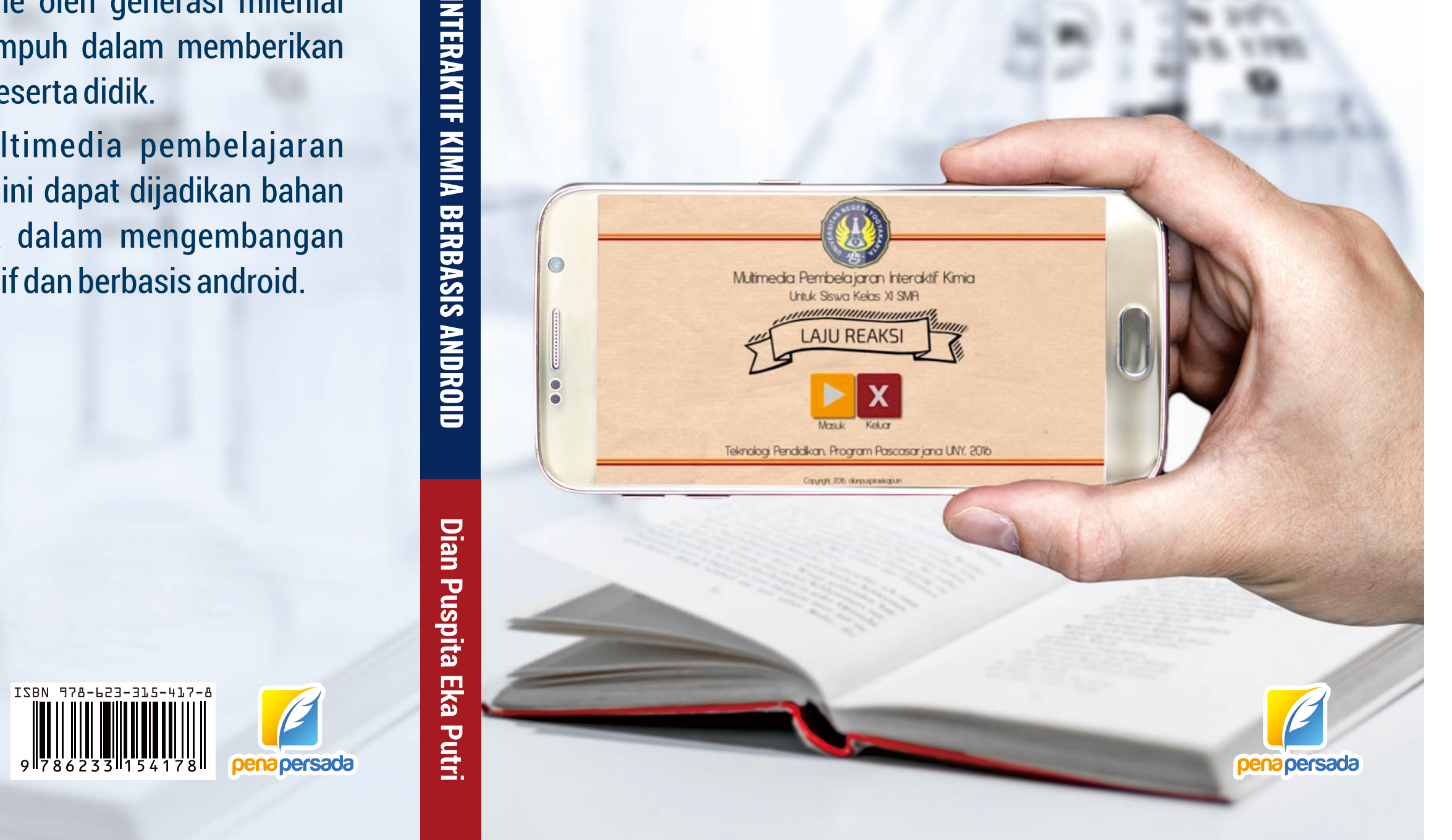


\title{
PENGEMBANGAN MULTIMEDIA \\ PEMBELAJARAN INTERAKTIF KIMIA BERBASIS ANDROID
}

\author{
DIAN PUSPITA EKA PUTRI
}

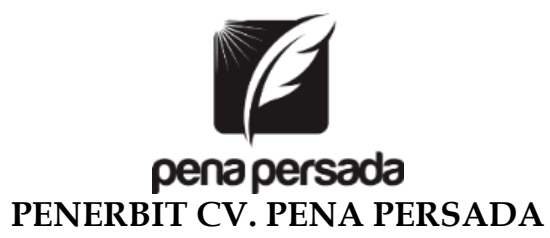




\title{
PENGEMBANGAN MULTIMEDIA \\ PEMBELAJARAN INTERAKTIF KIMIA \\ BERBASIS ANDROID
}

\author{
Penulis: \\ Dian Puspita Eka Putri \\ ISBN: 978-623-315-417-8 \\ Editor: \\ Rusfik Yulli Anur Wati \\ Design Cover: \\ Retnani Nur Briliant
}

\author{
Layout: \\ Nisa Falahia
}

\section{Penerbit CV. Pena Persada}

Redaksi:

Jl. Gerilya No. 292 Purwokerto Selatan, Kab. Banyumas

Jawa Tengah

Email: penerbit.penapersada@gmail.com

Website: penapersada.com Phone: (0281) 7771388

\section{Anggota IKAPI}

All right reserved

Cetakan pertama: 2021

Hak Cipta dilindungi oleh undang-undang. Dilarang memperbanyak karya tulis ini dalam bentuk apapun tanpa izin penerbit 


\section{KATA PENGANTAR}

Segala puji senantiasa kita panjatkan kehadirat Allah Swt, atas segala rahmat dan karunianya, akhirnya penulis dapat menyelesaikan penyusunan buku yang berjudul "Pengembangan Multimedia Pembelajaran Interaktif Kimia Berbasis Android“. Saya menyadari bahwa tanpa bantuan dan bimbingan dari berbagai pihak sangatlah sulit bagi saya untuk menyelesaikan karya ini. Oleh karena itu, saya mengucapkan banyak terima kasih pada semua pihak yang telah membantu penyusunan buku ini. Sehingga buku ini bisa hadir di hadapan pembaca.

Dalam buku ini membahas tentang pengembangan multimedia pembelajaran interaktif kimia berbasis android menggunakan prinsip mayer pada materi laju reaksi untuk siswa SMA Kelas XI. Kajian ini bertujuan untuk: (1) mengetahui karakteristik produk multimedia pembelajaran interaktif berbasis android menggunakan prinsip Mayer yang layak untuk materi laju reaksi (2) menguji keefektifan produk multimedia pembelajaran interaktif kimia dalam meningkatkan capaian hasil belajar kognitif siswa pada materi laju reaksi.

Penulis menyadari bahwa buku ini masih jauh dari kesempurnaan. Oleh karena itu kritik dan saran yang membangun sangat dibutuhkan guna penyempurnaan buku ini. Akhir kata saya berharap Allah Swt berkenan membalas segala kebaikan semua pihak yang telah membantu

Penulis 


\section{DAFTAR ISI}

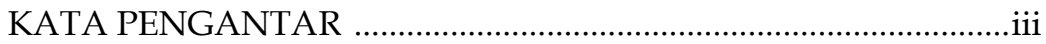

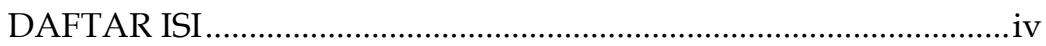

BAB I PENDAHULUAN …………………………...................... 1

A. Peran Ilmu Kimia dalam Kehidupan .................................. 1

B. Kondisi Pencapaian Pembelajaran Kimia ............................. 2

C. Upaya dalam Mencapai Tujuan Pembelajaran Kimia ....... 4

BAB II PEMBELAJARAN KIMIA SMA ............................................... 7

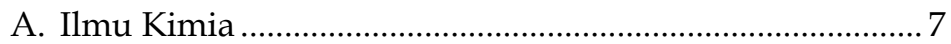

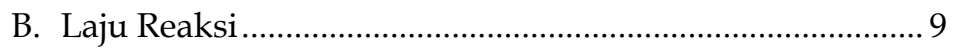

C. Pelaksanaan Pembelajaran Kimia SMA ............................. 10

D. Karakteristik dan Ruang Lingkup Mata Pelajaran

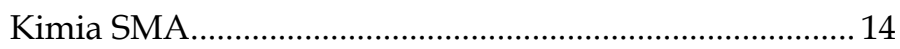

E. Hasil Belajar Kimia .............................................................. 15

BAB III MULTIMEDIA PEMBELAJARAN INTERAKTIF ................ 18

A. Pengertian Multimedia Pembelajaran Interaktif

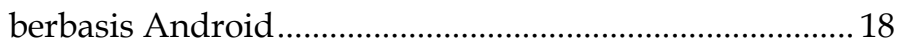

B. Komponen-Komponen Multimedia Pembelajarn

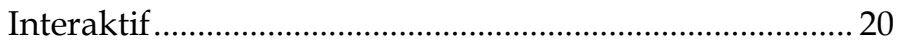

C. Karakteristik Multimedia Pembelajaran Interaktif .......... 24

D. Kriteria Penilaian Multimedia Pembelajaran Interaktif . 26

BAB IV PENGEMBANGAN MULTIMEDIA PEMBELAJARAN INTERAKTIF BERBASIS ANDROID MENGGUNAKAN PRINSIP MAYER …………………………….................... 30

A. Penerapan Prinsip Mayer dalam Pengembangan Multimedia Pembelajaran Interaktif .................................. 30

B. Tahapan Pengembangan Multimedia Pembelajaran

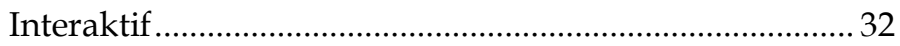

C. Teori Belajar yang Melandasi Pengembangan Multimedia Pembelajaran Interaktif ....................................35

D. Kedudukan Karakteristik Siswa dalam Pengembangan Produk ......................................................... 40

E. Kedudukan Pengembangan Multimedia Pembelajaran dalam Kawasan Teknologi Pembelajaran . 


\section{BAB $\mathrm{V}$ PENERAPAN PENGEMBANGAN MULTIMEDIA PEMBELAJARAN INTERAKTIF..............................................4}

A. Tahap Perencanaan .......................................................... 44

1. Ruang Lingkup Materi......................................................4

2. Identifikasi Karakter Siswa ...........................................45

3. Pengumpulan Sumber .................................................. 46

4. Brainstorming (Diskusi Ide Awal) ..................................47

5. Dokumen perencanaan ................................................... 47

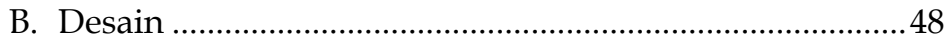

1. Pembuatan Flowchart .....................................................48

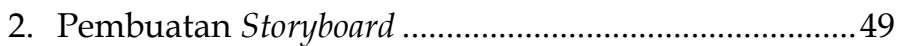

3. Perancangan Naskah Materi ..........................................49

C. Tahap Pengembangan ........................................................ 49

1. Penyiapan Elemen-Elemen Media yang digunakan..49

2. Pembuatan Produk ........................................................50

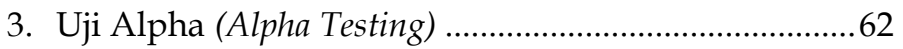

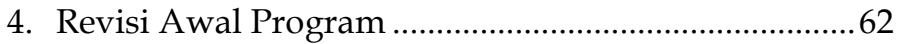

5. Uji Beta (Beta Testing) …………………………............62

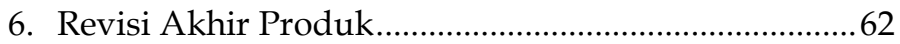

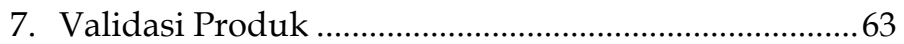

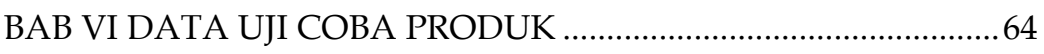

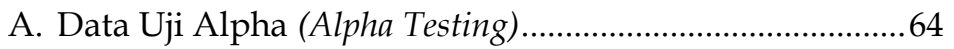

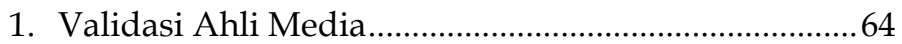

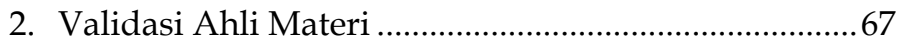

B. Data Uji Beta (Beta Testing) .................................................. 70

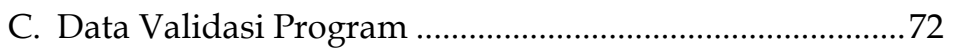

D. Data Capaian Hasil Belajar Kognitif.....................................74

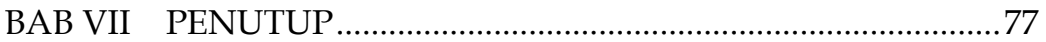

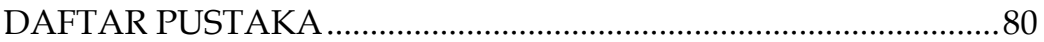

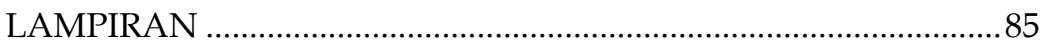




\section{PENGEMBANGAN MULTIMEDIA \\ PEMBELAJARAN INTERAKTIF KIMIA BERBASIS ANDROID}




\section{BAB I \\ PENDAHULUAN}

\section{A. Peran Ilmu Kimia dalam Kehidupan}

Kimia merupakan salah satu cabang ilmu pengetahuan alam yang diperuntukkan untuk siswa pada jenjang SMA/SMK/MA dan sederajat. Ilmu kimia mengkaji segala bentuk materi yang ada di alam. Siswa dituntut untuk memiliki kompetensi memahami konsep teori, memahami fakta, serta memahami hukum prinsip teori kejadian-kejadian yang ada di alam secara matang, sehingga siswa dapat mengimplementasikan ilmu tersebut dalam kehidupan seharihari. Dengan kata lain kimia adalah kelompok mata pelajaran ilmu pengetahuan yang membahas fenomena-fenomen alam seperti komponen, cara kerja suatu sistem dan unsur-unsur yang terkandung di dalam sistem tersebut. Diharapkan dengan adanya pengetahuan ini siswa dapat memecahkan permasalahan yang ditemui dalam kehidupan sehari-hari.

Kimia sebagai kelompok ilmu pengetahuan dan teknologi memiliki kompetensi lanjut yang menuntut siswa memiliki pengetahuan faktual, konseptual, prosedural dan metakognitif dalam ilmu pengetahuan (Permendikbud No 20 tahun 2016 tentang standar kompetensi lulusan untuk satuan pendidikan dasar dan menengah). Sejalan dengan hal tersebut, karakteristik kurikulum 2013 juga menuntut siswa untuk membentuk karakter berfikir secara ilmiah dengan menggunakan pendekatan saintifik. Pembelajaran kimia dengan pendekatan saintifik pada kurikulum 2013 ini memiliki tujuan agar siswa dapat membentuk sikap positif serta mengagungkan kebesaran Tuhan Yang Maha Esa, memiliki sikap ilmiah, mampu memecahkan masalah secara sistematik dan untuk meningkatkatkan kemampuan intelektual siswa (Permendikbud No 103 Tahun 2014 tentang Pembelajaran Pada Pendidikan Dasar dan Pendidikan Menengah). 
Tujuan tersebut dapat dicapai apabila seluruh komponen pembelajaran bersinergi dengan baik. Komponen tersebut dapat berupa tujuan pembelajaran, materi pembelajaran, strategi dan metode, media dan sumber, karakteristik siswa serta karakter materi kimia itu sendiri. Hasil belajar yang diharapkan harus mengacu pada tujuan pembelajaran setelah penyampaian materi yang diajarkan. Pemilihan strategi, metode media bantu belajar dan sumber belajar harus efektif dan efisien, serta tepat digunakan untuk menunjang pembelajaran sesuai dengan karakteristik materi dan karakteristik siswa (Degeng, 2013:216-221).

\section{B. Kondisi Pencapaian Pembelajaran Kimia}

Proses pembelajaran kimia yang terjadi selama ini belum mampu mencapai tujuan pembelajaran secara optimal. Siswa masih kesulitan memahami materi pembelajaran kimia yang ada. Hal tersebut dapat dilihat dari data yang diberikan Kemendikbud (2014) yang merilis laporan hasil analisis Ujian Nasional Tahun Ajaran (TA) 2014/2015. Laporan hasil analisis tersebut menyebutkan bahwa daya serap kimia belum mencapai kriteria daya serap minimum (70\%). Data yang diperlihatkan tersebut menunjukkan bahwa tujuan pembelajaran untuk mata pelajaran kimia secara nasional belum tercapai.

Fakta lain yang juga ditemukan dalam laporan hasil analisis Ujian Nasional TA 2014/2015 menunjukkan bahwa mata pelajaran kimia menempati urutan daya serap paling rendah dibandingkan dengan mata pelajaran lain yang diujikan untuk program belajar IPA. Perbandingan persentase daya serap tersebut antara lain; Bahasa Indonesia (71,20\%), fisika $(64,51 \%)$, Bahasa Inggris $(64,33 \%)$, matematika $(60,12 \%)$, biologi (61,02\%), dan kimia (59,82\%) (Kemdikbud, 2014). Berdasarkan wawancara yang dilakukan dengan salah satu guru pengampu mata pelajaran kimia di SMAN 9 Yogyakarta pada tanggal 20 juli 2016 diketahui bahwa kesulitan ini disebabkan banyaknya materi kimia yang harus dipelajari namun waktu dan sumber belajar yang tersedia tidak 
mencukupi untuk mencapai tujuan dan hasil pembelajaran tersebut.

Ada beberapa faktor yang dapat mempengaruhi hasil belajar diantaranya yaitu kompetensi guru, sistem kurikulum, siswa, media pembelajaran yang digunakan lingkungan pembelajaran serta strategi dan metode pembelajaran (Sugiyarto, 2014:128). Komponen-komponen tersebut berperan penting dalam mencapai tujuan pembelajaran. Begitu juga dengan media pembelajaran, media pembelajaran merupakan faktor yang berpengaruh dalam mencapai efektifitas belajar. Oleh karena itu untuk meningkatkan efektivitas pembelajaran kimia diperlukan sumber atau media yang baik.

Laju reaksi adalah materi pembelajaran kimia yang diperuntukkan untuk siswa kelas XI SMA/SMK/MA dan sederajatnya. Kompetensi dasar yang harus dikuasai siswa pada materi laju reaksi adalah memahami teori tumbukan untuk menjelaskan suatu reaksi kimia dan menganalisis faktorfaktor yang mempengaruhi laju reaksi serta dapat menentukan orde reaksi berdasarkan data hasil percobaan (Permendikbud No 24 Tahun 2016 tentang Kompetensi Inti dan Kompetensi Dasar). Untuk mencapai kompetensi tersebut, pokok bahasan ini memuat banyak materi, baik teoritis maupun praktis.

Menurut laporan hasil belajar kimia kelas XI IPA SMAN 9 Yogyakarta diperoleh fakta yaitu, rata-rata terendah penguasaan materi pembelajaran kimia dengan kriteria ketuntasan minimum sebesar 70 dari Tahun Ajaran 2014/20152015/2016 adalah materi laju reaksi. Rata-rata persentase materi tersebut adalah: struktur atom $(77,39 \%)$, gaya antar molekul (77,83\%), termokimia (62,56\%), kesetimbangan $(71,79 \%)$ dan laju reaksi $(60,81 \%)$. Merujuk pada hasil analisis ujian akhir semester guru-guru kimia kelas XI SMAN 9 Yogyakarta tersebut maka dapat disimpulkan bahwa adanya kesulitan siswa dalam memahami materi laju reaksi, sehingga permasalahan ini harus dicarikan solusinya (Laporan Hasil Belajar Kimia Tahun Ajaran 2014/2015-2015/2016). 
Masalah lain terkait pembelajaran kimia khususnya materi laju reaksi yang diperoleh dari hasil observasi dan wawancara dengan salah satu guru kimia SMAN 9 Yogyakarta di antaranya adalah masih minimnya sumber belajar yang dapat memenuhi karakteristik materi dan karakteristik siswa. Sejauh ini sumber belajar yang biasa digunakan berupa buku paket dan Lembar Kerja Siswa (LKS). Buku paket dan LKS yang digunakan selama ini belum mampu mengoptimalkan hasil belajar siswa. Hal ini dikarenakan buku paket dan LKS mempunyai keterbatasan dalam menyampaikan dan menghadirkan pesan isi materi laju reaksi dalam bentuk nyata. Karakteristik materi laju reaksi yang bersifat abstrak membutuhkan visualisasi yang dapat menggambarkan kejadian dan faktor-faktor yang mempengaruhi laju reaksi tersebut secara lebih real. Oleh karena itu dibutuhkan sumber belajar dalam bentuk yang lebih nyata.

\section{Upaya dalam Mencapai Tujuan Pembelajaran Kimia}

Berdasarkan wawancara yang dilakukan dengan salah satu guru kimia dan beberapa siswa di SMAN 9 Yogyakarta diketahui bahwa pembelajaran kimia saat ini sudah memakai media dalam upayanya mencapai tujuan pembelajaran. Media yang digunakan berupa media infocus dan slide presentasi serta alat-alat praktikum pada pembelajaran praktikum kimia di laboratorium. Media ini dirasakan belum optimal dalam menunjang pencapaian tujuan pembelajaran. Media ini masih memiliki keterbatasan dalam menyampaikan materi laju reaksi secara lebih konkrit dan penggunaannya terbatas di kelas saja.

Menurut pemaparan siswa SMAN 9 Yogyakarta, materi laju reaksi adalah materi yang sulit untuk dipahami, sehingga siswa membutuhkan media yang mampu menghadirkan animasi yang dapat memvisualisasikan materi laju reaksi menjadi lebih konkrit serta dapat digunakan kapan saja dan dimana saja. Penggunaan media yang efektif diharapkan dapat membantu siswa dalam menguasai materi. Hal ini sejalan dengan penelitian yang dilakukan oleh yektyastuti (2012:13) yang menyimpulkan bahwa peningkatan efektifitas pencapaian 
tujuan pembelajaran terjadi apabila suatu materi yang bersifat abstrak dapat disajikan dalam bentuk yang lebih konkrit dan realistis. Salah satu media yang memiliki kemampuan tersebut adalah multimedia, multimedia dapat memberikan visualisasi materi dalam bentuk animasi sehingga pesan dari materi laju reaksi dapat tersampaikan dengan lebih konkrit kepada siswa.

Mayer (2009) mengemukakan beberapa prinsip yang harus diperhatikan dalam pengembangan multimedia yang baik. Prinsip-prinsip tersebut adalah: (1) prinsip multimedia, (2) prinsip keterdekatan ruang, (3) prinsip keterdekatan waktu, (4) prinsip koherensi, (5) prinsip modalitas belajar, (6) prinsip redudansi, (7) prinsip interaktivitas. Milavonavic (2013:132) menyebutkan bahwa pengembangan multimedia dengan menggunakan prinsip mayer dapat meminimalisir kesalahan yang menyebabkan media pembelajaran tidak efektif jika dibandingkan dengan beberapa prinsip lainnya. Dengan demikian, penggunaan prinsip Mayer dalam mengembangkan multimedia pembelajaran akan dapat menghasilkan media pembelajaran yang lebih baik dan efektif.

Multimedia juga merupakan salah satu media yang dapat memenuhi berbagai gaya belajar siswa. Multimedia memiliki berbagai komponen media yang mendukungnya seperti teks, gambar, audio dan video. Komponen-komponen tersebut dapat mendukung berbagai gaya belajar siswa (Rita, Jeffrey dan Angela, 2002:167),

Penggunaan multimedia pembelajaran akan lebih optimal jika didukung oleh device yang mudah digunakan, salah satunya adalah smartphone. Fenomena sistem operasi smartphone di Indonesia yang penggunaannya paling tinggi adalah sistem operasi berbasis Android. Android adalah sistem operasi yang sifatnya open lisence yang memungkinkan siapapun untuk mengembangkan berbagai aplikasi termasuk aplikasi pembelajaran. Menurut data yang di lansir pada situs gs.statcounter.com menunjukkan bahwa terjadinya peningkatan yang sangat pesat tentang penggunaan smartphone berbasis android sebanyak $49,86 \%$ yaitu dari 
18,53\% per-agustus 2012 menjadi 68,39\% per-agustus 2015. Hal ini diperkuat dengan data yang diperoleh dari siswa SMAN 9 Yogyakarta yang menyebutkan bahwa, dari 30 orang siswa yang memiliki smartphone, terdapat sebanyak $90 \%$ menggunakan smartphone berbasis Android dan smartphone berbasis IOS sebanyak $10 \%$.

Pengembangan multimedia berbasis android dalam kajian ini bertujuan untuk mengoptimalkan kelebihan teknologi dalam menunjang keberhasilan pembelajaran sehingga perkembangan teknologi akan membawa dampak positif. Media berbasis android sebenarnya telah banyak dikembangkan, namun kebanyakan belum memperhatikan prinsip-prinsip multimedia yang baik (Mariano, 2014:4). Maka kajian ini dimaksudkan untuk mengembangkan multimedia sebagai alat bantu belajar siswa, sehingga siswa dapat belajar secara mandiri kapanpun dan dimanapun. Oleh karena itu pengembangan multimedia berbasis android menggunakan prinsip Mayer ini diharapkan dapat meningkatkan hasil belajar kognitif siswa kelas XI SMA pada mata pelajaran kimia materi laju reaksi.

Berdasarkan uraian latar belakang diatas judul kajian ini adalah "Pengembangan Multimedia Pembelajaran Interaktif Kimia Berbasis Android Menggunakan Prinsip Mayer Pada Materi Laju Reaksi Untuk Siswa SMA Kelas XI". 


\section{BAB II \\ PEMBELAJARAN KIMIA SMA}

\section{A. Ilmu Kimia}

Ilmu kimia menurut Silberberg 1984:2) adalah ilmu yang mempelajari tentang struktur, komposisi, sifat dan perubahan dari suatu materi baik itu yang dialami secara alamiah maupun dalam proses eksperimen yang direncanakan. Menurut Brady (1990:3), ilmu kimia merupakan ilmu yang mempelajari tentang bahan-bahan kimia serta segala permasalahan yang meliputinya. Permasalahan tersebut berupa: bagaimana pembentukan suatu senyawa, bagaimana atom berikatan satu sama lain, apa kegunaan dari suatu material, bagaimana suatu reaksi dapat berlangsung dan bagaimana keseluruhan materi kimia dapat dimanfaatkan dalam kehidupan manusia.

Chang (2001:4) berpendapat bahwa ilmu kimia adalah ilmu yang mempelajari tentang peristiwa atau fenomena yang terjadi di alam, dengan fokus kajian adalah materi serta perubahan yang menyertainya. Lebih jauh Kean dan middlecamp (1985:6) menyebutkan bahwa ilmu kimia merupakan salah satu cabang ilmu sains yang tumbuh dan berkembang berdasarkan pengamatan dan penelitian terhadap suatu materi dan gejala alam yang terjadi.

Berdasarkan beberapa pendapat yang telah dikemukakan oleh para ahli tersebut, garis besar persamaan definisi ilmu kimia adalah ilmu yang mempelajari tentang suatu materi dan perubahan yang terjadi terhadap materi tersebut. Kelebihan definisi menurut Silberberg ialah disebutkannya proses pengkajian perubahan materi tidak hanya terjadi secara alami, melainkan juga dapat terjadi secara eksperimen yang direncanakan. Sedangkan para ahli lain mendefinisikan ilmu kimia sebagai perubahan materi yang terjadi secara alamiah. Jadi kesimpulan definisi ilmu kimia berdasarkan analisis tersebut adalah ilmu yang mempelajari 
suatu materi secara keseluruhan isinya dan mempelajari perubahan yang terjadi pada materi tersebut, baik yang terjadi secara alami maupun buatan.

Penggolongan ilmu kimia menurut Chang (2001:8) ada lima yaitu:

1. Biokimia, adalah cabang ilmu kimia yang mempelajari tentang proses-proses yang terjadi dalam tubuh makhluk hidup. Pokok bahasan biokimia adalah lemak, karbohidrat, senyawa siklik dan gugus fungsional

2. Kimia organik, merupakan ilmu yang mempelajari tentang sintesis senyawa-senyawa organik. pokok bahasan kimia organik adalah hidrokarbon dan tata nama senyawa organik

3. Kimia anorganik, adalah ilmu yang mempelajari tentang sifat-sifat senyawa anorganik seperti garam, mineral dan lain-lain. pokok bahasan kimia anorganik adalah asam-basa, reaksi asam basa, tata nama senyawa anorganik, struktur atom, sistem periodik dan kimia unsur

4. Kimia analitik, adalah ilmu yang mempelajari tentang cara memisahkan, mengidentifikasi jenis zat penyusun suatu bahan serta menentukan jumlahnya. Pokok bahasan kimia analitik adalah larutan, elektrokimia, titrasi asam basa dan pemisahan senyawa pada materi kimia lingkungan

5. Kimia fisik, adalah topik ilmu kimia yang mempelajari mengenai suatu zat dalam skala makroskopik, atomik dan subatomik pada suatu sistem kimia dengan hukum-hukum dan konsep fisika yang berlaku. Pokok bahasan dalam kimia fisik adalah termokimia, laju reaksi, faktor-faktor penyebab laju reaksi, kesetimbangan kimia, derajat ionisasi, larutan, stoikiometri dan reaksi redoks

Cabang-cabang ilmu kimia seperti yang telah dijelaskan sebelumnya menunjukkan bahwa cakupan materi ilmu kimia sangat luas. Luasnya ruang lingkup materi ilmu kimia tersebut, menjadikan karakteristik ilmu kimia bersifat kompleks dan abstrak. Pendapat ini didukung oleh Kean dan middlecamp (1985:5-8) menyebutkan bahwa sebagian besar ilmu kimia 
bersifat abstrak sehingga diperlukan suatu media yang dapat menyederhanakan konsep-konsep abstrak tersebut.

\section{B. Laju Reaksi}

Laju reaksi merupakan salah satu pokok bahasan kimia fisik. Laju reaksi menurut Chang (2001:45) adalah berkurangnya jumlah pereaksi dalam tiap satuan waktu atau bertambahnya hasil reaksi dalam tiap satuan waktu. Menurut Silberberg (1984:83), laju reaksi merupakan pernyataan yang menjelaskan tentang perubahan konsentrasi reaktan atau produk dalam suatu reaksi kimia. Definisi lain dikemukakan oleh Brady (1990:112) yang menyebutkan bahwa laju reaksi adalah besarnya laju perubahan konsentrasi zat-zat komponen reaksi dalam tiap satuan waktu.

Uraian tersebut menjelaskan bahwa keseluruhan definisi memiliki pendapat yang sama mengenai laju reaksi. Secara matematis laju reaksi dirumuskan sebagai perubahan konsentrasi pereaksi atau hasil reaksi dibagi dengan besarnya perubahan satuan waktu. Jadi dapat disimpulkan laju reaksi adalah besarnya laju dari perubahan konsentrasi komponen reaksi (pereaksi atau hasil reaksi) dalam tiap satuan waktu.

Ruang lingkup materi laju reaksi adalah konsep laju reaksi, teori tumbukan, persamaan laju reaksi, faktor-faktor yang mempengaruhi laju reaksi dan penentuan orde reaksi. Materi pembelajaran laju reaksi merupakan kombinasi dari materi teoritis dan materi hitungan matematis. Adanya kombinasi materi teori dan hitungan matematis menyebabkan materi laju reaksi ini cenderung sulit untuk dipahami. Sejalan dengan pendapat tersebut Kasmadi dan Indraspuri (2010:273) menyebutkan bahwa kesulitan materi laju reaksi disebabkan oleh luasnya cakupan materi yang harus dikuasai dan sebagian besar materi tersebut bersifat teori dan hitungan sehingga membutuhkan nalar dan kemampuan matematis siswa untuk memahaminya.

Permendikbud No 242016 tentang standar kelulusan menjelaskan bahwa kompetensi yang harus dikuasai siswa pada materi laju reaksi ini adalah siswa dapat Memahami teori 
tumbukan (tabrakan) untuk menjelaskan reaksi kimia, dapat Menganalisis faktor-faktor yang mempengaruhi laju reaksi dan menentukan orde reaksi berdasarkan data hasil percobaan. Tujuan pembelajaran yang dapat diturunkan dari kompetensi yang ingin dicapai pada materi laju reaksi ini adalah Siswa dapat:

1. Menjelaskan konsep laju reaksi,

2. Menjelaskan teori tumbukan,

3. Menyebutkan faktor-faktor yang mempengaruhi laju reaksi,

4. Menjelaskan pengaruh konsentrasi terhadap laju reaksi,

5. Menjelaskan pengaruh suhu terhadap laju reaksi,

6. Menjelaskan pengaruh luas permukaan bidang sentuh terhadap laju reaksi,

7. Menjelaskan pengaruh katalis terhadap laju reaksi,

8. Menentukan besar laju reaksi, menentukan besar konstanta laju reaksi dan

9. Menentukan orde reaksi berdasarkan analisis data percobaan yang diberikan

Dengan memperhatikan karakteristik dan ruang lingkup materi laju reaksi tersebut, maka proses pembelajaran kimia khususnya materi laju reaksi harus menggunakan metode yang sesuai dengan karakteristik konsep/materi laju reaksi itu sendiri. Salah satu metode tersebut adalah penggunaan media pembelajaran yang tepat sesuai dengan karakteristik materi laju reaksi. Oleh karena itu perlu adanya pengembangan suatu media yang dapat membantu siswa dalam memahami materi laju reaksi dan mencapai tujuan pembelajaran.

\section{Pelaksanaan Pembelajaran Kimia SMA}

Pembelajaran menurut Munir (2008:152) adalah proses perumusan ilmu pengetahuan secara aktif, bukan hanya sekedar proses pengungkapan ilmu. Menurut Suparman (2012:10), pembelajaran adalah rangkaian kegiatan yang telah direncanakan oleh pengajar yang terarah pada hasil belajar tertentu. Sejalan dengan hal tersebut Gafur (2012:4) menyebutkan bahwa pembelajaran adalah proses penyampaian 
pesan, gagasan, ide, fakta yang dirancang sedemikian rupa agar dapat diterima oleh penerima pesan.

Pendapat lain dikemukakan oleh Sanjaya (2012:219), Pembelajaran adalah suatu proses berpikir untuk mencari dan menemukan pengetahuan dengan cara interaksi antara individu dengan lingkungannya. Definisi lain yang mendukung pendapat ini dikemukakan oleh Slameto (2003:2), pembelajaran merupakan proses komunikasi dua arah antara guru sebagai pendidik dan siswa sebagai peserta didik untuk mencapai tujuan pembelajaran.

Uraian para ahli tersebut menunjukan adanya perbedaan dan persamaan pendapat mengenai pembelajaran. Perbedaan pendapat tersebut terletak pada cara atau proses pembelajaran itu dilakukan. Menurut Gafur dan Suparman proses pembelajaran telah direncanakan sehingga tujuan belajar tersebut dapat tercapai. Sedangkan menurut Slameto dan Sanjaya proses pembelajaran adalah proses interaksi komunikasi antara guru dan siswa. Persamaan keseluruhan pendapat mengenai pembelajaran adalah suatu proses kegiatan untuk mendapatkan pengetahuan dan tujuan belajar tertentu. Berdasarkan pendapat yang dikemukakan oleh para ahli tersebut dapat disimpulkan bahwa pembelajaran adalah proses atau rangkaian kegiatan yang terjadi akibat adanya interaksi dan komunikasi antara pengajar dan pembelajar sehingga diperoleh suatu pengetahuan dan tercapainya tujuan pembelajaran tertentu.

Pembelajaran kimia merupakan suatu proses kegiatan yang dilakukan oleh guru dengan materi bahan ajar ilmu kimia (Mulyasa,2006:56). Sementara itu menurut Resti, Sigit dan Ersanghono (2010:4), pembelajaran kimia merupakan kegiatan memperoleh pemahaman yang tahan lama perihal berbagai fakta-fakta kimia, kemampuan memecahkan masalah kimia, menguasai teknik laboratorium kimia dan mengembangkan sikap ilmiah. Pembelajaran kimia sekolah menengah bertujuan tidak hanya untuk menguasai pengetahuan kimia tetapi juga menguasai sikap ilmiah dan menerapkan ilmu kimia dalam 
kehidupan sehari-hari (Permendikbud No 65 Tahun 2013 tentang Standar Proses Pendidikan dasar dan menengah).

Keseluruhan pendapat tersebut sependapat bahwa materi yang dikaji dalam pembelajaran kimia adalah ilmu kimia. Namun pendapat yang dikemukan oleh Mulyasa tidak menjelaskan tujuan dari pembelajaran kimia tersebut. Sedangkan pembelajaran kimia menurut Resti, Sigit dan Ersanghono dan Permendikbud No 65 Tahun 2013 menjelaskan kemampuan yang ingin dicapai setelah proses kegian pembelajaran berlansung.

Berdasarkan uraian pendapat di atas dapat disimpulkan pembelajaran kimia adalah segala bentuk kegiatan interaksi dan komunikasi antara siswa dan guru untuk menguasai materi bahan ajar kimia, menguasai sikap ilmiah dan menerapkan ilmu kimia dalam kehidupan sehari-hari. Pembelajaran kimia dapat juga diartikan sebagai cara untuk memberikan pemahaman kepada siswa tentang kimia. Namun bila dilihat dari perannya dalam mewujudkan tujuan pembelajaran, peran pembelajaran kimia memiliki peran yang lebih dari itu. Pembelajaran kimia sebenarnya dapat digunakan untuk melatih peserta didik untuk dapat menggunakan konsep yang diterimanya dalam konteks yang sebenarnya. Pemahaman konsep bukan tujuan akhir dari pembelajaran kimia tetapi lebih jauh lagi adalah bagaimana pemahaman konsep itu digunakan dalam proses pemecahan masalah yang dihadapinya di lingkungan (alam).

Menurut Mulyasa (2006:133-134), pembelajaran kimia di SMA/MA bertujuan agar siswa memiliki kemampuan sebagai berikut:

1. Membentuk sikap positif terhadap kimia dan menyadari keteraturan dan keindahan alam serta mengagungkan kebesaran Tuhan Yang Maha Esa

2. Memupuk sikap ilmiah yaitu jujur, objektif, terbuka, ulet, kritis, dan dapat bekerja sama dengan orang lain

3. Memperoleh pengalaman dalam menerapkan metode ilmiah melalui percobaan atau eksperimen, dimana siswa 
melakukan pengujian hipotesis dengan merancang percobaan melalui pemasangan instrumen, pengambilan, pengolahan, dan penafsiran data, serta menyampaikan hasil percobaan secara lisan dan tertulis

4. Meningkatkan kesadaran tentang terapan kimia yang dapat bermanfaat dan juga merugikan bagi individu, masyarakat, dan lingkungan serta menyadari pentingnya mengelola dan melestarikan lingkungan dan kesejahteraan masyarakat

5. Memahami konsep, prinsip, hukum, dan teori kimia serta saling keterkaitannya dan penerapannya untuk menyelesaikan masalah dalam kehidupan sehari-hari dan teknologi.

Menurut Permendikbud No. 64 tahun 2013 tentang standar isi mata pelajaran kimia di kelas XI SMA/MA bertujuan agar siswa memiliki kompetensi sebagai berikut:

1. Menumbuhkan keimanan kepada Tuhan Yang Maha Esa melalui pengamatan terhadap fenomena dan prinsip kimia.

2. Mengembangkan sikap ilmiah: rasa ingin tahu, berpikir logis dan analitis, tekun, ulet, jujur, disiplin, tanggung jawab, santun, dan peduli melalui kimia.

3. Memahami struktur atom dan molekul, ikatan kimia, sifat fisik dan kimia unsur, keperiodikan sifat unsur, dan dapat mengaitkan struktur atom, jenis ikatan, struktur molekul dan interaksi antar molekul dengan sifat fisik dan kimianya yang teramati.

4. Menerapkan hukum-hukum dasar kimia, energetika, kinetika dan kesetimbangan untuk menjelaskan fenomena yang terkait seperti kespontanan reaksi dan faktor-faktor yang mempengaruhi jalannya suatu reaksi.

5. Merancang dan melakukan percobaan kimia yang mencakup perumusan masalah, mengajukan hipotesis, menentukan variabel, memilih instrumen, mengumpulkan, mengolah dan menganalisis data, menarik kesimpulan, dan mengkomunikasikan hasil percobaan secara lisan dan tertulis. 